\title{
Assessment and comparison of thermal stability of phosphorothioate-DNA, DNA, RNA, 2'-F RNA, and LNA in the context of Phi29 pRNA 3WJ
}

\author{
XIJUN PIAO, HONGZHI WANG, DANIEL W. BINZEL, and PEIXUAN GUO \\ Center for RNA Nanobiotechnology and Nanomedicine, The Ohio State University, Columbus, Ohio 43210, USA \\ College of Pharmacy, Division of Pharmaceutics and Pharmaceutical Chemistry, The Ohio State University, Columbus, Ohio 43210, USA \\ College of Medicine; Dorothy M. Davis Heart and Lung Research Institute; The Ohio State University, Columbus, Ohio 43210, USA \\ James Comprehensive Cancer Center, The Ohio State University, Columbus, Ohio 43210, USA
}

\begin{abstract}
The question of whether RNA is more stable or unstable compared to DNA or other nucleic acids has long been a subject of extensive scrutiny and public attention. Recently, thermodynamically stable and degradation-resistant RNA motifs have been utilized in RNA nanotechnology to build desired architectures and integrate multiple functional groups. Here we report the effects of phosphorothioate deoxyribonucleotides (PS-DNA), deoxyribonucleotides (DNA), ribonucleotides (RNA), 2'-F nucleotides (2'-F), and locked nucleic acids (LNA) on the thermal and in vivo stability of the three-way junction (3WJ) of bacteriophage phi29 motor packaging RNA. It was found that the thermal stability gradually increased following the order of PS-DNA/PS-DNA < DNA/DNA < DNA/RNA < RNA/RNA < RNA/2'-F RNA < 2'-F RNA/2'-F RNA < 2'-F RNA/LNA < LNA/LNA. This proposition is supported by studies on strand displacement and the melting of homogeneous and heterogeneous $3 W J s$. By simply mixing different chemically modified oligonucleotides, the thermal stability of phi29 pRNA 3WJ can be tuned to cover a wide range of melting temperatures from $21.2^{\circ} \mathrm{C}$ to over $95^{\circ} \mathrm{C}$. The $3 W J_{L N A}$ was resistant to boiling temperature denaturation, urea denaturation, and $50 \%$ serum degradation. Intravenous injection of fluorescent $\mathrm{LNA} / \mathbf{2}^{\prime}-\mathrm{F}$ hybrid $3 \mathrm{WJs}$ into mice revealed its exceptional in vivo stability and presence in urine. It is thus concluded that incorporation of LNA nucleotides, alone or in combination with 2'-F, into RNA nanoparticles derived from phi29 pRNA 3WJ can extend the half-life of the RNA nanoparticles in vivo and improve their pharmacokinetics profile.
\end{abstract}

Keywords: three-way junction; thermal stability; in vivo stability; RNA nanotechnology; chemical modification; RNA 4D structure

\section{INTRODUCTION}

The "central dogma" states that DNA makes RNA then makes protein, and protein plays a major role in life function (Crick 1958). However, the completion of the first human genome sequencing argued that only $1.5 \%$ of the human genome coded for protein. A significant percentage of the human genome was believed to be a junk DNA scaffold. But more and more evidence from the subsequent studies shows that part of the so-called junk DNA actually code for small (Moss 2001; Calin and Croce 2006; Ghildiyal and Zamore 2009; Tiemann and Rossi 2009; Zhang 2009; Liu and Paroo 2010; Wiedenheft et al. 2012), or long (Mercer et al. 2009; Morlando et al. 2014) noncoding RNAs that regulate cellular activities. It has been speculated that in addition to the two milestones of chemical and protein drugs in the history of drug development, a third milestone is predicted to be RNA as drugs or drugs targeting to RNA (Shu et al. 2014).

Corresponding author: guo.1091@osu.edu

Article is online at http://www.rnajournal.org/cgi/doi/10.1261/rna.063057. 117.
The versatility in RNA structures, low energy in RNA folding, and amenability in structure control provide feasibility in RNA drug development. However, the question of whether RNA is more stable or unstable compared to DNA or other nucleic acids has long been under extensive scrutiny and public attention.

The field of RNA nanotechnology has emerged rapidly (Guo 2010; Jasinski et al. 2017) since the proof-of-concept in 1998, when it was found that RNA dimer, trimer, tetramer, and hexamer can be produced via bottom-up assembly of fabricated RNA fragments derived from the pRNA subunit of phi29 DNA packaging motor (Guo et al. 1998). Currently, the concept of RNA nanotechnology has been defined (Guo and Haque 2013; Jasinski et al. 2017): RNA nanotechnology is the bottom-up self-assembly of nanometer scale RNA architectures with its major frame composed of

(C) 2018 Piao et al. This article is distributed exclusively by the RNA Society for the first 12 months after the full-issue publication date (see http:/ rnajournal.cshlp.org/site/misc/terms.xhtml). After 12 months, it is available under a Creative Commons License (Attribution-NonCommercial 4.0 International), as described at http://creativecommons.org/licenses/by-nc/4.0/. 
RNA. In RNA nanoparticles, the scaffolds, ligands, therapeutics, regulators can all be composed of RNA. RNA nanotechnology is a unique field that is distinct from the classical studies on RNA structure and function, which focus on intra-RNA interactions and 2D/3D structures. RNA nanotechnology focuses on inter-RNA interactions and quaternary (4D) structures (Guo et al. 1998; Jaeger and Leontis 2000; Jaeger et al. 2001; Chworos et al. 2004; Shu et al. 2004, 2011; Afonin et al. 2008, 2014; Grabow and Jaeger 2014; Li et al. 2015; Sharma et al. 2015).

Two major engineering steps have been used to construct RNA nanoparticles. The first step is the utilization of the spontaneous self-folding property of RNA into defined structures by base/base interaction. Based on the calculation of the Gibbs free energy $\Delta G$, a variety of RNA sequences can be predicted via computational algorithms and tested empirically based on the prediction of the secondary or tertiary structure (Gai et al. 2004; Yingling and Shapiro 2007; Afonin et al. 2010; Geary et al. 2014). The second step is the use of the naturally occurring RNA motifs as building blocks to assemble RNA nanoparticles based on the predicted quaternary architectures (Lundbaek and Andersen 1994; Westhof et al. 1996; Shu et al. 2004, 2011; Severcan et al. 2010; Dibrov et al. 2011; Grabow et al. 2011; Khisamutdinov et al. 2014, 2016; Li et al. 2016).

Many types of RNA three-way junctions and four-way junctions have been found in nature (Duckett et al. 1995; Felden et al. 1996; Rettberg et al. 1999; Diamond et al. 2001; Hohng et al. 2004; Leontis et al. 2006; Lescoute and Westhof 2006; de la Peña et al. 2009; Ouellet et al. 2010) and can be used for the fabrication of RNA nanoparticles. In particular, the phi2 9 bacteriophage DNA motor packaging RNA (pRNA) three-way junction (Fig. 1A-C) was found to efficiently self-assemble from three RNA fragments and exhibit an exceptional thermodynamic stability. RNA and DNA folding is dependent on energy landscape as described by $\Delta G=\Delta H-T \Delta S$. While enthalpy change $(\Delta H)$ is more relevant to heat, and entropy change $(\Delta S)$ relates to the structuring, the two factors are significant in considering RNA and DNA complex production and assembly. Duplex hybridization is believed to be driven by a lower enthalpy value (Gyi et al. 1996; Rauzan et al. 2013); however, our previous study showed pRNA 3WJ assembly was governed more by entropy change than by enthalpy change (Binzel et al. 2014, 2016a). That is, the structuring factor plays a key role in $3 \mathrm{WJ}$ assembly. It has been reported that the three fragments of the pRNA $3 \mathrm{WJ}$ coassembled with extraordinary speed and affinity via a two-step mechanism. The first step between $3 \mathrm{WJ}-\mathrm{b}$ and $3 \mathrm{WJ}-$ $c$ is highly dynamic since these two fragments only contain eight complementary base pairs. Though enthalpy change plays an important role at this step, we believe entropy change is key to the idea of "irreversibility." More specifically, formation of the $3 \mathrm{WJ}-\mathrm{b}+3 \mathrm{WJ}-\mathrm{c}$ dimer generates a special structure with a fixed angle and two protruding sequences (Zhang et al. 2013; Binzel et al. 2016a). Such a structure is an entropically favorable receptor for $3 \mathrm{WJ}-\mathrm{a}$, which contains 17 -nt complementary to the formed dimer complex. Thus, the second step occurs at a very high association rate and locks the unstable dimer into a highly stable 3WJ (Binzel et al. 2016a). Consequently, the pRNA $3 \mathrm{WJ}$ is more stable than any of
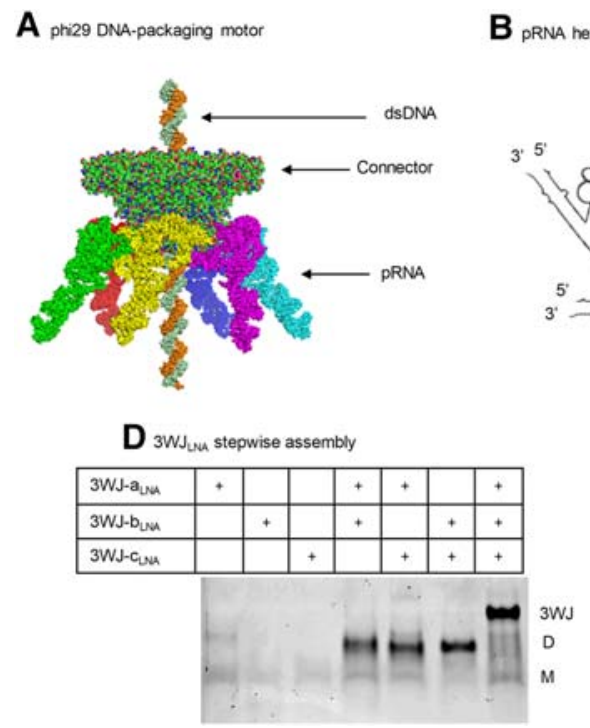
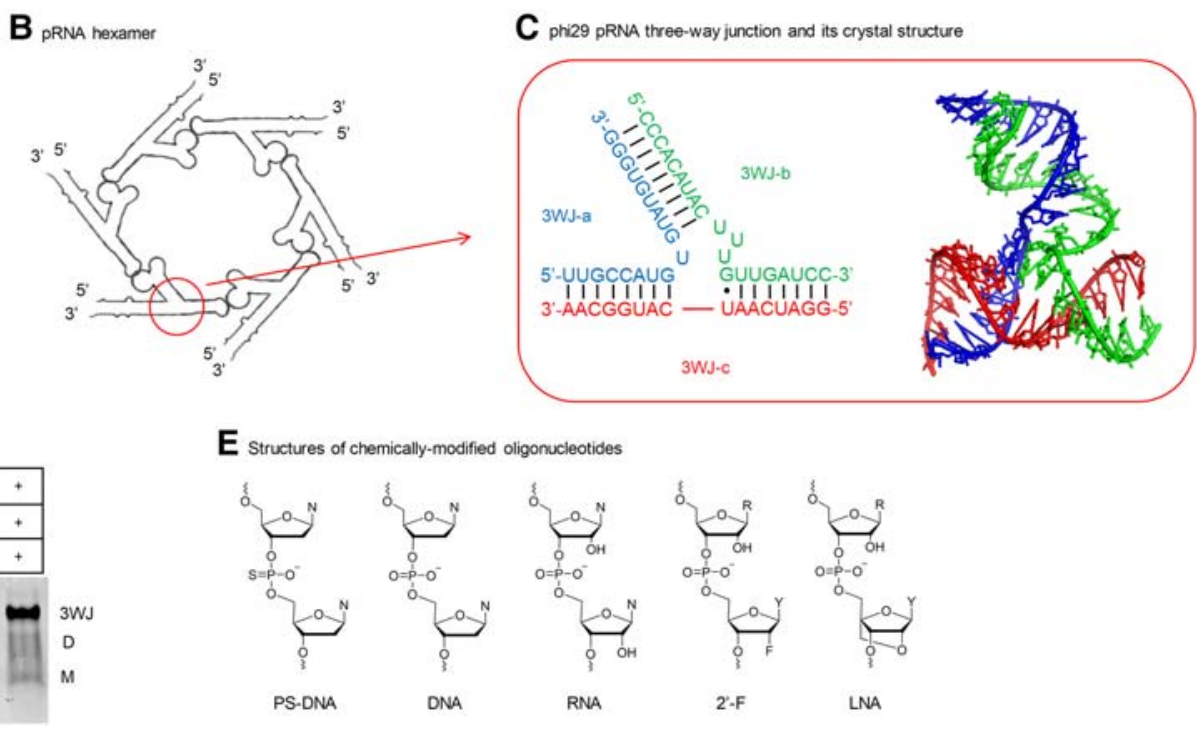

FIGURE 1. Structures of phi29 DNA-packaging motor, pRNA hexamer, pRNA $3 \mathrm{WJ}$, stepwise assembly of homogeneous $3 \mathrm{WJ} \mathrm{LNA}_{\mathrm{LN}}$, and structures of five different chemically modified oligonucleotides. (A) Structure of phi29 DNA-packaging motor. (B) Packaging RNA (pRNA) hexamer. (C) Phi29 pRNA $3 \mathrm{WJ}$ and its crystal structure. (D) Stepwise assembly of $3 \mathrm{WJ}_{\mathrm{LNA}}$. (Short single-stranded oligonucleotides and some chemically modified oligonucleotides respond to $\mathrm{EtBr}$ staining differently. Thus, LNA single strands are stained weakly and are not very clear to see in this example.) $\mathrm{M}$ indicates the migration of monomer. D indicates the migration of dimer. $3 \mathrm{WJ}$ indicates the migration of three-way junction. $(E)$ Structures of chemically modified oligonucleotides (2'-F denotes 2 '-fluoro-U/C-modified oligonucleotides and LNA denotes LNA-U/C-modified oligonucleotides). 
the dimer species, as shown in the much more rapid association rate and smallest dissociation rate constant, creating a more irreversible association of three strands. These findings support the claim that pRNA 3WJ assembly was governed more by entropy (Binzel et al. 2014, 2016a). Furthermore, this robust RNA $3 \mathrm{WJ}$ stays intact at ultralow concentration, is resistant to a high molar urea denaturation (Shu et al. 2011), and also remains stable under high mechanical rupture forces (Xu et al. 2017). In addition, substituting uridine and cytidine with their $2^{\prime}$-fluoro-modified counterparts further increases nanoparticle stability and prevents digestion by RNases (Layzer et al. 2004). 2'-F modified phi29 pRNA $3 \mathrm{WJ}$ thus greatly enhances the thermodynamic and enzymatic stability of RNA nanoparticles and has paved the way for medical applications of RNA nanotechnology (Cui et al. 2015; Shu et al. 2015; Binzel et al. 2016b; Zhang et al. 2017).

Recent clinical trials of chemically modified oligonucleotides (Burnett and Rossi 2012; Lundin et al. 2015; Khvorova and Watts 2017) and the FDA approval of a phosphorothioate-modified oligonucleotide (Stein and Castanotto 2017) clearly indicate the importance of chemical modifications in medical applications of RNA nanotechnology. Extensive studies have been performed on the effects of chemical modifications on the thermodynamic stability (De Mesmaeker et al. 1995; Vester and Wengel 2004; Karkare and Bhatnagar 2006) and chemical stability (Kawasaki et al. 1993; Heidenreich et al. 1994; Allerson et al. 2005) of duplex and triplex (Betts et al. 1995; Kaur et al. 2006; Hansen et al. 2009; Piao et al. 2013). For example, in a DNA duplex, each $2^{\prime}$-methoxy- (2'-OMe-) or 2'-fluoro- (2'-F-) modified nucleoside has been shown to increase the $T_{\mathrm{m}}$ by $1^{\circ} \mathrm{C}-2^{\circ} \mathrm{C}$ (Kawasaki et al. 1993). Additionally, modifications with phosphorothioate-DNA (PS-DNA), 2'-F, 2'-OMe, and locked nucleic acid (LNA) have been shown to increase the rather short half-life seen in unmodified siRNAs (Shaw et al. 1991; Kawasaki et al. 1993; Elmen et al. 2005). While few studies have been published on more complex RNA structures (e.g., RNA 3WJs), a more complete understanding of how chemically modified oligonucleotides affect the thermal and in vivo stability of the pRNA three-way junction is essential for future clinical applications of RNA nanotechnology.

To this end, we have previously measured thermodynamic parameters for phi29 pRNA 3WJ composed of DNA, RNA, and 2'-F RNA. However, in vitro and in vivo stability against enzymatic degradation was not discussed (Binzel et al. 2014). We herein extend our previous efforts in $3 \mathrm{WJ}$ thermodynamics to two well-known nuclease-resistant oligonucleotides, PS-DNA and LNA. We assess and compare the melting temperatures of homogeneous and heterogeneous $3 \mathrm{WJ}$ s using temperature-gradient gel electrophoresis (TGGE), as well as modification-specific oligonucleotide affinity in strand displacement between single-stranded oligonucleotides and assembled 3WJs (Fig. 1D; Supplemental Fig. S1). In addition, we investigate the effects of chemical modifications (Fig. 1E) on the in vivo stability of highly thermostable phi29 pRNA 3WJ.

\section{RESULTS AND DISCUSSION}

\section{Melting of homogeneous 3WJs}

The melting of homogeneous 3WJs was assessed on TGGE, where a linearly increasing temperature gradient was applied perpendicular to the electrical current. Thus, each separate lane of the $3 \mathrm{WJ}$ sample was subjected to heating at a gradually increased temperature across the gel. Each lane on the gel was then integrated using ImageJ, thereby producing a melting curve for each $3 \mathrm{WJ}$ sample. The melting temperature $\left(T_{\mathrm{m}}\right)$ was determined when $50 \%$ of the assembled $3 \mathrm{WJ}$ s were dissociated (Binzel et al. 2014). Dissociation would result in a relatively sharp transition of the band, while the gradual migration rate increase from left to right was most notably due to the swelling of gel pores at elevated temperatures.

With the exception of $3 \mathrm{WJ}_{\mathrm{LNA}}$, all other homogeneous $3 \mathrm{WJ}$ showed a relatively sharp increase in migration rate, suggesting the dissociation of one or two strands (Fig. 2). The $T_{\mathrm{m}} \mathrm{s}$ generated from TGGE at the concentration of $10 \mu \mathrm{M}$ were calculated to be $21.2^{\circ} \mathrm{C}, 39.3^{\circ} \mathrm{C}, 58.0^{\circ} \mathrm{C}$, and $67.5^{\circ} \mathrm{C}$ for homogeneous $3 \mathrm{WJ}_{\mathrm{PS}-\mathrm{DNA}}, 3 \mathrm{WJ}_{\mathrm{DNA}}, 3 \mathrm{WJ}_{\mathrm{RNA}}$ and $3 \mathrm{WJ}_{2^{\prime}-\mathrm{F}}$, respectively (Table 1 ), consistent with our previous observations (Binzel et al. 2014). The $3 \mathrm{WJ}_{\mathrm{LNA}}$ did not show a sharp transition in migration rate on the gel, indicating it did not melt at $80^{\circ} \mathrm{C}$ heating, as this is the temperature limitation of the TGGE. Clearly, the thermal stability of phi29 pRNA $3 \mathrm{WJ}$, expressed as $T_{\mathrm{m}}$, was increased by chemical

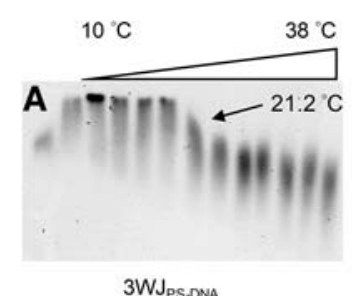

3WJ PS-DNA

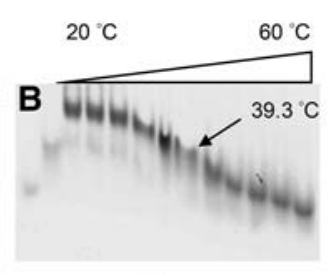

$3 \mathrm{WJ}_{\mathrm{DNA}}$

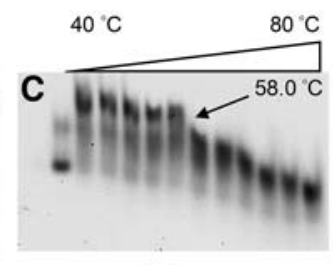

$3 \mathrm{WJ}_{\text {PNA }}$

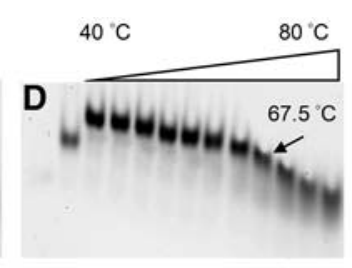

$3 \mathrm{WJ}_{2 \cdot \mathrm{F}}$

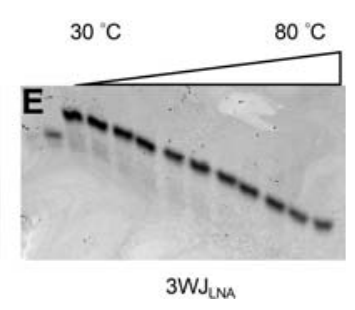

FIGURE 2. Melting of homogeneous $3 \mathrm{WJ}$ s on TGGE. (A) Melting of $3 \mathrm{WJ}_{\mathrm{PS}-\mathrm{DNA}}$ from $10^{\circ} \mathrm{C}$ to $38^{\circ} \mathrm{C}$. $(B) \mathrm{Melting}$ of $3 \mathrm{WJ} \mathrm{DNA}$ from $20^{\circ} \mathrm{C}$ to $60^{\circ} \mathrm{C}$. (C) Melting of $3 \mathrm{WJ}_{\mathrm{RNA}}$ from $40^{\circ} \mathrm{C}$ to $80^{\circ} \mathrm{C}$. (D) Melting of $3 \mathrm{WJ}_{2^{\prime}-\mathrm{F}}$ from $40^{\circ} \mathrm{C}$ to $80^{\circ} \mathrm{C}$. (E) Melting of $3 \mathrm{WJ} \mathrm{LNA}$ from $30^{\circ} \mathrm{C}$ to $80^{\circ} \mathrm{C}$. Black arrow and number indicate $T_{\mathrm{m}}$. 
TABLE 1. $T_{\mathrm{m}}$ summary

\begin{tabular}{lcc}
\hline Oligonucleotide & $\begin{array}{c}T_{\mathrm{m}} \text { of homogeneous } \\
3 \mathrm{WJ}\left({ }^{\circ} \mathrm{C}\right)\end{array}$ & $\begin{array}{c}T_{\mathrm{m}} \text { of } 3 \mathrm{WJ} \text {-c in } \\
\text { hybrid } 3 \mathrm{WJ}\left({ }^{\circ} \mathrm{C}\right)\end{array}$ \\
\hline PS-DNA & 21.2 & 34.4 \\
DNA & 39.3 & 51.3 \\
RNA & 58.0 & 62.2 \\
2 $^{\prime}$-F RNA & 67.5 & 67.5 \\
LNA & $>80(95)^{\mathrm{a}}$ & $>80$ \\
\hline
\end{tabular}

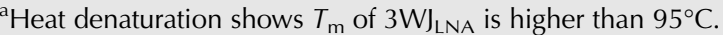

modifications in the order of PS-DNA $<$ DNA $<$ RNA $<2^{\prime}$-F RNA $<$ LNA.

\section{Melting of heterogeneous $3 \mathrm{WJs}$}

To further confirm the contribution of different chemically modified oligonucleotides to the thermal stability of the phi29 pRNA 3WJ, TGGE assays were performed on heterogeneous $3 \mathrm{WJ}$ s with only one variant strand. The $3 \mathrm{WJ}-\mathrm{c}$ was labeled with ${ }^{32} \mathrm{P}$ for tracking the dissociation of the $3 \mathrm{WJ}$. The resulting gels were stained by EtBr first to evaluate the melting of overall hybrid $3 \mathrm{WJ}$ structure before phosphorimaging. Assembly of the hybrid 3WJs was confirmed through a stepwise assembly gel with monomer and dimer controls. Phosphorimaging clearly showed the dissociation of $3 \mathrm{WJ}-$ $\mathrm{c}_{\mathrm{PS}-\mathrm{DNA}}, 3 \mathrm{WJ}-\mathrm{c}_{\mathrm{DNA}}, 3 \mathrm{WJ}-\mathrm{c}_{\mathrm{RNA}}$, and $3 \mathrm{WJ}-\mathrm{c}_{2^{\prime}-\mathrm{F}}$ from each hybrid $3 \mathrm{WJ}$ at $34.4^{\circ} \mathrm{C}, 51.3^{\circ} \mathrm{C}, 62.2^{\circ} \mathrm{C}$, and $67.5^{\circ} \mathrm{C}$, respectively (Table 1). The $3 \mathrm{WJ}-\mathrm{c}_{\mathrm{LNA}}$ strand still did not yield a transition below $80^{\circ} \mathrm{C}$ (Fig. 3F-J). This further confirms the order of the stabilizing effect (PS-DNA $<$ DNA $<$ RNA $<2^{\prime}$-F RNA $<$ LNA) of the five oligonucleotides within phi29 pRNA 3WJ.

Surprisingly, EtBr imaging displayed only one clear melting transition with a $T_{\mathrm{m}}$ around $64.5^{\circ} \mathrm{C}-67.5^{\circ} \mathrm{C}$ for all hybrid $3 \mathrm{WJ}$ except for the LNA hybrid $3 \mathrm{WJ}$ (Fig. 3A-E), even including PS-DNA and DNA hybrid $3 \mathrm{WJ}$ in which the $3 \mathrm{WJ}-\mathrm{c}$ had a much lower $T_{\mathrm{m}}$. The difference in these results could be due to the similar mobility of the $3 \mathrm{WJ}-\mathrm{a}_{2^{\prime}-\mathrm{F}}+3 \mathrm{WJ}-$ $\mathrm{b}_{2^{\prime}-\mathrm{F}}$ dimer and the hybrid $3 \mathrm{WJ}_{2^{\prime} \text {-F/PS-DNA }}$ or $3 \mathrm{WJ}_{2^{\prime}-\mathrm{F} / \mathrm{DNA}}$ on $12 \%$ native PAGE (Supplemental Fig. S2). In this case, the only $T_{\mathrm{m}}$ derived from migration was from the melting of $3 \mathrm{WJ}-\mathrm{a}_{2^{\prime}-\mathrm{F}}+3 \mathrm{WJ}-\mathrm{b}_{2^{\prime}-\mathrm{F}}$ dimer (Supplemental Fig. S3). However, phosphorimaging provided a confident marker to assay the dissociation of the labeled strand. This led to the elucidation of a distinctive two-step dissociation for PS-DNA and DNA hybrid $3 \mathrm{WJ}$ s through the combination of the EtBr staining and phosphorimaging of the gels. On the other hand, $3 \mathrm{WJ}-$ $\mathrm{C}_{\mathrm{RNA}}$ dissociated from RNA hybrid $3 \mathrm{WJ}$ was seen only slightly before the melting of $3 \mathrm{WJ}-\mathrm{a}_{2^{\prime}-\mathrm{F}}+3 \mathrm{WJ}-\mathrm{b}_{2^{\prime}-\mathrm{F}}$ dimer, indicating RNA and 2'-F RNA had a similar contribution to the thermal stability of $3 \mathrm{WJ}$. Such a small difference in $T_{\mathrm{m}}$ would easily be omitted by other assays, demonstrating the advantage of TGGE in monitoring the exact behavior of a specific component in a multiple-stranded system and distinguishing a small difference of melting temperatures. The melting curve of individual $3 \mathrm{WJ}-\mathrm{c}_{2^{\prime}-\mathrm{F}}$ was nearly identical to the overall melting of $3 \mathrm{WJ}_{2^{\prime}-\mathrm{F}}$, suggestive of a cooperative melting of homogeneous $3 \mathrm{WJ}$ due to the close affinities of three $2^{\prime}$-F RNA strands. LNA hybrid $3 \mathrm{WJ}$ exhibited $20 \%$ to $30 \%$ dissociation based on the melting of individual $3 \mathrm{WJ}-\mathrm{c}_{\mathrm{LNA}}$ or the overall $3 \mathrm{WJ}$ on the gel, suggestive of a $T_{\mathrm{m}}$ higher than $80^{\circ} \mathrm{C}$.

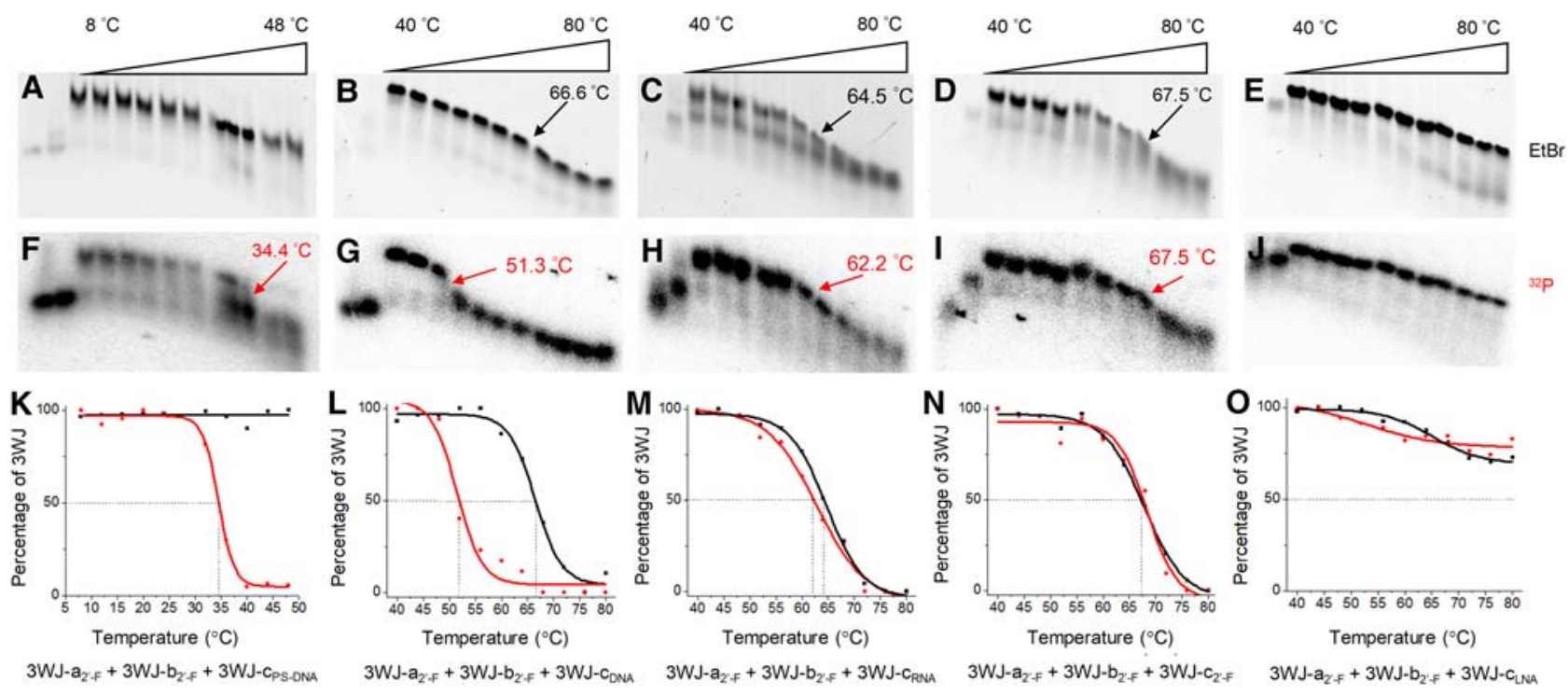

FIGURE 3. Melting of hybrid 3WJs (3WJ-c is ${ }^{32} \mathrm{P}$-labeled). The first two lanes of each sample are monomer and dimer as controls. Red curve is melting curve from phosphorimaging; black curve is melting curve from EtBr channel. Red arrow and number indicate $T_{\mathrm{m}}$ of c strand in hybrid $3 \mathrm{WJ}$. Black arrow and number indicate $T_{\mathrm{m}}$ of $3 \mathrm{WJ}-\mathrm{a}_{2^{\prime}-\mathrm{F}}+3 \mathrm{WJ}-\mathrm{b}_{2^{\prime}-\mathrm{F} \cdot}(A, F, K)$ Melting of PS-DNA hybrid $3 \mathrm{WJ}$. $(B, G, L)$ Melting of DNA hybrid 3WJ. (C,H,M) Melting of RNA hybrid 3WJ. (D,I,N) Melting of 2'-F homogeneous 3WJ. (E,J,O) Melting of LNA hybrid 3WJ. Bottom graphs are overlap of melting curves of $3 \mathrm{WJ}-\mathrm{c}$ (phosphorimaging, $F-J$ ) and the hybrid $3 \mathrm{WJ}$ (EtBr staining, $A-E$ ) for each hybrid $3 \mathrm{WJ}$. 


\section{Strand displacement assay by chemically modified replacement strands}

The strand displacement of preassembled pRNA 3WJ by individual chemically modified replacement strands was assessed to examine the variance in strand affinity over the competitor $3 \mathrm{WJ}$ strand. To investigate the strand displacement between different single-stranded oligonucleotide and assembled $3 \mathrm{WJs},{ }^{32} \mathrm{P}$-labeled $3 \mathrm{WJ}-\mathrm{c}_{\mathrm{DNA}}, 3 \mathrm{WJ}-\mathrm{c}_{\mathrm{RNA}}$, $3 \mathrm{WJ}-\mathrm{c}_{2^{\prime}-\mathrm{F}}$, and $3 \mathrm{WJ}-\mathrm{c}_{\mathrm{LNA}}$ were incubated with assembled nonlabeled homogeneous $3 \mathrm{WJ}_{\mathrm{DNA}}, 3 \mathrm{WJ}_{\mathrm{RNA}}, 3 \mathrm{WJ}_{2^{\prime}-\mathrm{F}}$, and $3 \mathrm{WJ}_{\mathrm{LNA}}$ at $37^{\circ} \mathrm{C}$ for $3 \mathrm{~h}$, respectively. PS-DNA was not included in this study because the $T_{\mathrm{m}} \mathrm{s}$ of $3 \mathrm{WJ} \mathrm{JS}_{\mathrm{PS} \text {-DNA }}$ and $3 \mathrm{WJ}-\mathrm{c}_{\mathrm{PS}-\mathrm{DNA}}$ in its hybrid $3 \mathrm{WJ}$ were lower than $37^{\circ} \mathrm{C}$, limiting its potential for in vivo applications.

As expected, $3 \mathrm{WJ}-\mathrm{c}_{\mathrm{LNA}}$ was able to completely displace $3 \mathrm{WJ}-\mathrm{c}_{\mathrm{DNA}}$ and $3 \mathrm{WJ}-\mathrm{c}_{\mathrm{RNA}}$ from their homogeneous $3 \mathrm{WJ}$, with partial displacement of the $3 \mathrm{WJ}-\mathrm{c}_{2^{\prime}-\mathrm{F}}$ on the $3 \mathrm{WJ}_{2^{\prime}-\mathrm{F}}$. The $3 \mathrm{WJ}-\mathrm{c}_{2^{\prime}-\mathrm{F}}$ also displayed strong thermodynamic stability and was able to fully displace $3 \mathrm{WJ}-\mathrm{c}_{\mathrm{DNA}}$ and $3 \mathrm{WJ}-\mathrm{c}_{\mathrm{RNA}}$ from their homogeneous $3 \mathrm{WJ}$, and to partially displace $3 \mathrm{WJ}-\mathrm{c}_{2^{\prime}-\mathrm{F}}$

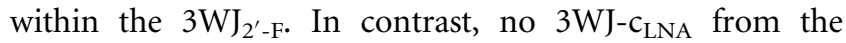
$3 \mathrm{WJ}_{\mathrm{LNA}}$ was displaced by $3 \mathrm{WJ}-\mathrm{c}_{2^{\prime}-\mathrm{F}}$, demonstrating the higher stabilization of the $3 \mathrm{WJ}$ composed of LNA and affinity of LNA over 2'-F RNA to the remaining two strands on the $3 \mathrm{WJ}$. Continuing the same stability trends seen in the TGGE studies, $3 \mathrm{WJ}-\mathrm{c}_{\mathrm{RNA}}$ demonstrated replacement in the $3 \mathrm{WJ}_{\mathrm{DNA}}$, partially for the $3 \mathrm{WJ}_{\mathrm{RNA}}$, and weakly for the $3 \mathrm{WJ}_{2^{\prime}-\mathrm{F}}$; that is, a decreasing displacement yield from $3 \mathrm{WJ}_{\mathrm{DNA}}$ to $3 \mathrm{WJ}_{2^{\prime}-\mathrm{F}}$. Again, the $3 \mathrm{WJ}_{\text {LNA }}$ was not vulnerable to such strand displacement and replacement. Finally, each of the $3 \mathrm{WJs}$ was resistant to $3 \mathrm{WJ}-\mathrm{c}_{\mathrm{DNA}}$ displacement with the exception of the $3 \mathrm{WJ}_{\mathrm{DNA}}$ (Fig. 4). The strand displacement results clearly show that LNA has the strongest stabilizing effect among the four different oligonucleotides, while DNA has the weakest. The dis- placement profiles for $2^{\prime}$-F RNA and RNA are similar, but RNA replaces a smaller percentage of the competitor strand compared to 2 - $-\mathrm{F} \mathrm{RNA}$ for $3 \mathrm{WJ}_{\mathrm{DNA}}$ and $3 \mathrm{WJ}_{\mathrm{RNA}}$. This may indicate that the difference of the stabilizing effect for these two oligonucleotides is not as dramatic between RNA/DNA or LNA $/ 2^{\prime}-\mathrm{F}$ RNA, with RNA slightly less than $2^{\prime}-\mathrm{F}$ RNA. These data are consistent with the melting of homogeneous $3 \mathrm{WJs}$, as the $T_{\mathrm{m}}$ difference between $3 \mathrm{WJ}_{2^{\prime}-\mathrm{F}}$ and $3 \mathrm{WJ}_{\mathrm{RNA}}$ is smaller than that of $3 \mathrm{WJ}_{\mathrm{RNA}}$ to $3 \mathrm{WJ}_{\mathrm{DNA}}$ and $3 \mathrm{WJ}_{\mathrm{LNA}}$ to $3 \mathrm{WJ}_{2^{\prime}-\mathrm{F}}$. This is also evidenced by the difference in $T_{\mathrm{m}} \mathrm{s}$ of different $3 \mathrm{WJ}-\mathrm{c}$ strands in hybrid $3 \mathrm{WJ}$ s, as the $T_{\mathrm{m}}$ difference between $3 \mathrm{WJ}-\mathrm{c}_{2^{\prime}-\mathrm{F}}$ and $3 \mathrm{WJ}-\mathrm{c}_{\mathrm{RNA}}$ is the smallest among all $\mathrm{c}$ strands in hybrid $3 \mathrm{WJ}$ (Table 1). Overall, the strand displacement results are consistent with the melting data, and further confirm that the stabilizing trend of these oligonucleotides to the pRNA 3 WJ was DNA $<$ RNA $<2$ '-F RNA $<$ LNA.

\section{In vitro characterization of LNA/2'-F hybrid $3 W J \mathbf{s}$}

The exceptional stabilizing effect of LNA led to characterization of the $3 \mathrm{WJ}_{\mathrm{LNA}}$ further through more in depth thermodynamic analysis to gain a better understanding of the melting temperature of LNA modified $3 \mathrm{WJ}$ s. As $T_{\mathrm{m}}$ is concentration dependent, we attempted to measure $T_{\mathrm{m}}$ for the $3 \mathrm{WJ}_{\mathrm{LNA}}$ at lowered concentrations; however, its $T_{\mathrm{m}}$ still remained above $95^{\circ} \mathrm{C}$ even at the lowest concentration detectable. This rendered the accurate $T_{\mathrm{m}}$ measurement difficult. Thus, we studied heat denaturation of ${ }^{32} \mathrm{P}$-labeled LNA $/ 2^{\prime}-\mathrm{F}$ hybrid $3 \mathrm{WJ}$ s at a low concentration of $16 \mathrm{nM}$ in the presence of 50 -fold excess nonradiolabeled competitors to prevent renaturation. Even at this lowered concentration, homogeneous $3 \mathrm{WJ}_{\mathrm{LNA}}$ was found to be resistant to heat denaturation at $95^{\circ} \mathrm{C}$ for at least $5 \mathrm{~min}$, as only $\sim 16 \%$ of ${ }^{32} \mathrm{P}$-labeled $3 \mathrm{WJ}$ - $\mathrm{c}_{\mathrm{LNA}}$ was displaced by the excess nonradiolabeled $3 \mathrm{WJ}-\mathrm{c}_{\mathrm{LNA}}$. In order to

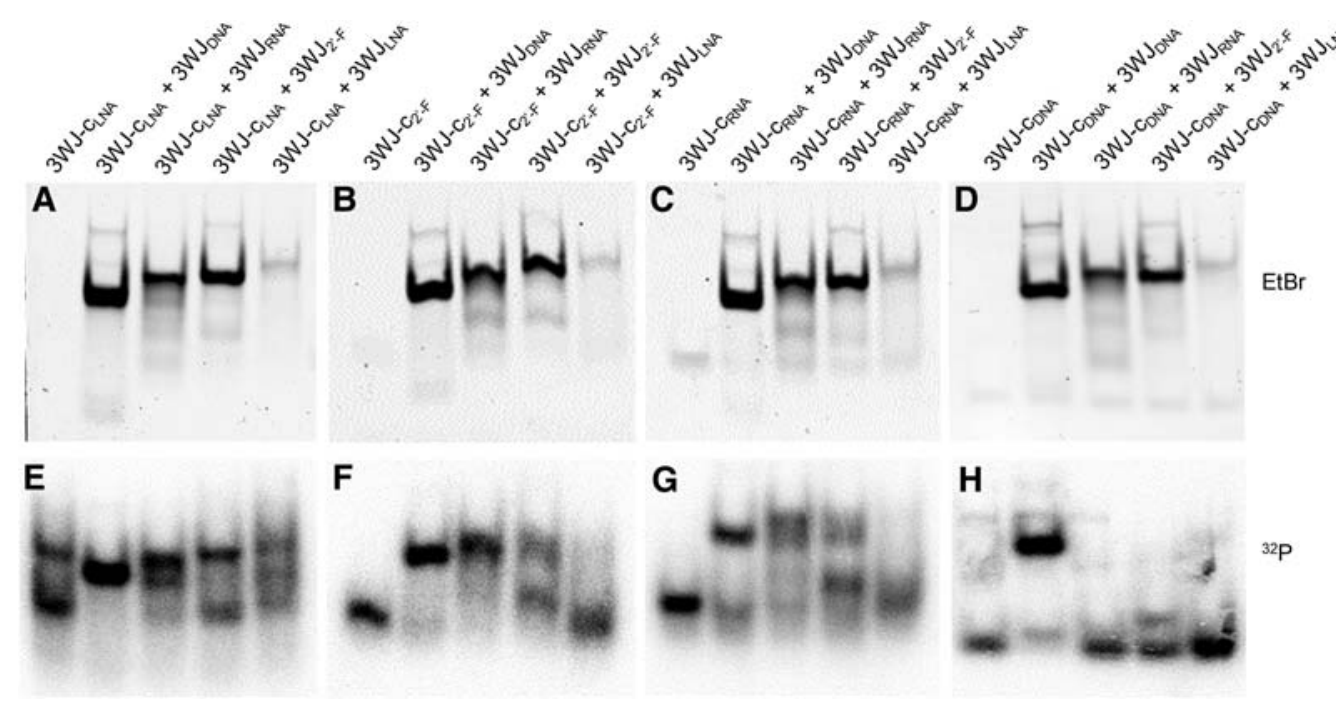

FIGURE 4. Strand displacement between radiolabeled single-stranded $3 \mathrm{WJ}-\mathrm{c}$ and assembled homogeneous $3 \mathrm{WJ}$ s. (A,E) LNA displaces $3 \mathrm{WJ}$ s. (B,F) 2'-F RNA displaces 3WJs. $(C, G)$ RNA displaces 3WJs. $(D, H)$ DNA displaces 3WJs. $(A-D)$ EtBr channel; $(E-H)$ phosphorimaging. 
examine a melting temperature, a series of $3 \mathrm{WJ}_{\mathrm{LNA} / 2^{\prime}-\mathrm{F}}$ hybrids were created, and it was found that decreasing the LNA content resulted in a lowered $T_{\mathrm{m}}$. Consequently, a $2 / 3$ $3 \mathrm{WJ}_{\mathrm{LNA}}\left(3 \mathrm{WJ}-\mathrm{a}_{2^{\prime}-\mathrm{F}}+3 \mathrm{WJ}-\mathrm{b}_{\mathrm{LNA}}+3 \mathrm{WJ}-\mathrm{c}_{\mathrm{LNA}}\right)$ appeared vulnerable to heat denaturation with 50 -fold excess competitors (Fig. 5A,B), but still did not display a melting profile below $80^{\circ} \mathrm{C}$ by TGGE analysis. Further reduction of the ratio of LNA in $3 \mathrm{WJ}$ to $1 / 3\left(3 \mathrm{WJ}-\mathrm{a}_{2^{\prime}-\mathrm{F}}+3 \mathrm{WJ}-\mathrm{b}_{2^{\prime}-\mathrm{F}}+3 \mathrm{WJ}-\mathrm{c}_{\mathrm{LNA}}\right)$ led to a sharp drop of $T_{\mathrm{m}}$ to $74^{\circ} \mathrm{C}$, while the $3 \mathrm{WJ}_{2^{\prime}-\mathrm{F}}$ at $16 \mathrm{nM}$ melted at $57^{\circ} \mathrm{C}$. Despite distinctive melting temperatures, all four LNA $/ 2^{\prime}$-F hybrid 3WJs showed similar apparent equilibrium dissociation constants in the low nanomolar range (Table 2). The high melting temperatures of homogeneous and heterogeneous LNA 3WJs led us to select them for resistance against denaturing reagents. Like the heat denaturation experiment, these two $3 \mathrm{WJ} s\left(3 \mathrm{WJ} \mathrm{JNA}_{\mathrm{LN}}\right.$ and $\left.2 / 33 \mathrm{WJ}_{\mathrm{LNA}}\right)$ were found resistant to $8 \mathrm{M}$ urea at $37^{\circ} \mathrm{C}$ in an assay in the presence of 100-fold excess competitors (Fig. 5C). Taken together, the high $T_{\mathrm{m}}$, low $K_{\mathrm{d}}$ and resistance to $8 \mathrm{M}$ urea suggest that the high thermodynamic stability of LNA modified 3WJs.

To further evaluate the potential application of LNA $/ 2{ }^{\prime}-\mathrm{F}$ hybrid 3WJs for in vivo applications, we investigated their stabilities in $50 \%$ of fetal bovine serum, mimicking the in vivo serum concentrations. Serum stability of the $3 \mathrm{WJ}$ s was assayed by electrophoretic analysis of RNA nanoparticles incubated in the serum over varying time points. Increasing the ratio of LNA content in hybrid 3WJs resulted in dramatic improved stability of $3 \mathrm{WJ}$ s. Incorporation of one LNA strand extended the half-life of homogeneous $3 \mathrm{WJ}_{2^{\prime}-\mathrm{F}}$ from 7.7 to 16.6 h. The $2 / 33 \mathrm{WJ} \mathrm{JNA}_{\mathrm{LA}}$ and homogeneous $3 \mathrm{WJ}_{\mathrm{LNA}}$ exhibited similar half-lives of above $48 \mathrm{~h}$ assayed in these studies (Fig. 5D). Overall, these findings led us to the conclusion that LNA 3WJs were found superiorly thermodynamically stable and resistant to serum degradation, overcoming the two major hurdles commonly seen in other nanotechnology platforms, thus providing promise in use for in vivo drug carrier applications.

\section{In vivo stability of $L N A / 2^{\prime}-F 3 W J s$ and urine assay upon IV injection}

As a drug delivery platform, RNA nanoparticles usually integrate multiple functional modules, including cancer cell-targeting motif, signal-reporting group and therapeutic reagent. High thermodynamic stability and strong resistance to degradation are thus desired to keep RNA nanoparticles intact and remain as an all-in-one carrier of necessary modules. To assess the in vivo stability of LNA $/ 2$ '-F $3 \mathrm{WJ}$ s, intravenous injections of fluorescent $2 / 33 \mathrm{WJ}_{\mathrm{LNA}}\left(3 \mathrm{WJ}-\mathrm{a}_{\mathrm{LNA}}+3 \mathrm{WJ}-\mathrm{b}_{\mathrm{LNA}}+\right.$ $3 \mathrm{WJ}-\mathrm{c}_{2^{\prime}-\mathrm{F}}$ labeled with Alexa647) and homogeneous $3 \mathrm{WJ}_{2^{\prime}-\mathrm{F}}$ $\left(3 \mathrm{WJ}-\mathrm{a}_{2^{\prime}-\mathrm{F}}+3 \mathrm{WJ}-\mathrm{b}_{2^{\prime}-\mathrm{F}}+3 \mathrm{WJ}-\mathrm{c}_{2^{\prime}-\mathrm{F}}\right.$ labeled with Alexa647) were performed in BALB/c mice. Whole-body imaging (Supplemental Fig. S4) displayed rapid biodistribution of the nanoparticles throughout the mice with a rapid clearance of $\sim 40 \%$ of nanoparticles within the first hour by urinary excretion, similar to the study of antisense oligonucleotides (Zhang et al. 1995). In order to examine the stability of the $3 \mathrm{WJ}$ in vivo, urine samples were collected from the mice during this period of rapid clearance. Analysis of collected urine by native PAGE showed the majority of homogeneous $3 \mathrm{WJ}_{2^{\prime}-\mathrm{F}}$ was degraded within the first $1 \mathrm{~h}$. This result is not surprising, as similar chemically modified oligonucleotides were reported to be mostly degraded to products with lower molecular weights, via urine assays, though the oligonucleotides absorbed into body tissues were shown to remain stable at $6 \mathrm{~h}$ (Agrawal et al. 1995). Most strikingly, no significant degradation of 2/3 LNA hybrid $3 \mathrm{WJ}$ was observed within the first hour compared to the injected samples, and $\sim 20 \%$ of $2 / 3$ LNA hybrid $3 \mathrm{WJ}$ was still found to be intact after urine excretion at $3 \mathrm{~h}$ (Fig. 6), suggestive of the super resistance of LNA $3 \mathrm{WJ}$ to in vivo degradation. In vitro incubation of both $3 \mathrm{WJ}$ samples in mouse urine further confirmed these results as no degradation was examined. While it cannot be concluded if the $2^{\prime}$-F RNA nanoparticles were degraded during blood
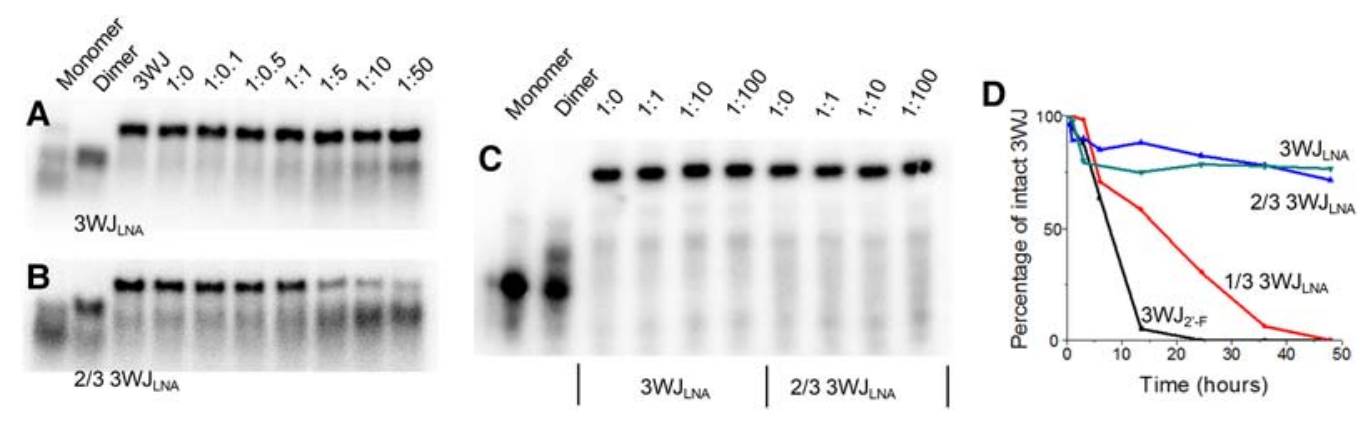

FIGURE 5. Thermal stability and stability against $50 \%$ serum of selected $3 \mathrm{WJ}$. ( $A$ ) Resistance to heat denaturation for homogeneous $3 \mathrm{WJ}$ LNA. $(B)$ Resistance to heat denaturation for hybrid $2 / 33 \mathrm{WJ}_{\mathrm{LNA}}$ (For $A$ and $B$, lane 1: monomer, ${ }^{32} \mathrm{P}$-labeled $3 \mathrm{WJ}-\mathrm{c}_{\mathrm{LNA}}$; lane 2 : dimer, ${ }^{32} \mathrm{P}-$ labeled $3 \mathrm{WJ}-\mathrm{c}_{\mathrm{LNA}}$ $+3 \mathrm{WJ}-\mathrm{a}_{\mathrm{LNA}}$; lane $3:{ }^{32} \mathrm{P}$-labeled $3 \mathrm{WJ}$ without heat denaturation; lanes 4-10: heat-denaturated $3 \mathrm{WJ}$ samples in the presence of increasing nonradiolabeled competitor up to 50-fold). (C) Resistance to $8 \mathrm{M}$ urea denaturation for homogeneous LNA 3WJ and 2/3 LNA hybrid 3WJ (all samples were incubated with $8 \mathrm{M}$ urea, lane 1: monomer, ${ }^{32} \mathrm{P}$-labeled $3 \mathrm{WJ}-\mathrm{c}_{\mathrm{LNA}}$; lane 2: dimer, ${ }^{32} \mathrm{P}$-labeled $3 \mathrm{WJ}-\mathrm{c}_{\mathrm{LNA}}+3 \mathrm{WJ}-\mathrm{a}_{\mathrm{LNA}}$; lanes $3-6: 3 \mathrm{WJ} \mathrm{INA}_{\text {in }}$ the presence of increasing nonradiolabeled competitor up to 100 -fold; lanes $7-10: 2 / 33 \mathrm{WJ}_{\mathrm{LNA}}$ in the presence of increasing nonradiolabeled competitor up to 100 -fold). (D) Stability of $3 \mathrm{WJ}$ in $50 \%$ serum (green: homogeneous $3 \mathrm{WJ}_{\mathrm{LNA}}, 3 \mathrm{WJ}-\mathrm{a}_{\mathrm{LNA}}+3 \mathrm{WJ}-\mathrm{b}_{\mathrm{LNA}}+3 \mathrm{WJ}-\mathrm{c}_{\mathrm{LNA}}$; blue: hybrid $2 / 33 \mathrm{WJ}_{\mathrm{LNA}}, 3 \mathrm{WJ}-\mathrm{a}_{2^{\prime}-\mathrm{F}}+3 \mathrm{WJ}-\mathrm{b}_{\mathrm{LNA}}+$ $3 \mathrm{WJ}-\mathrm{c}_{\mathrm{LNA}}$; red: hybrid $1 / 33 \mathrm{WJ}_{\mathrm{LNA}}, 3 \mathrm{WJ}-\mathrm{a}_{2^{\prime}-\mathrm{F}}+3 \mathrm{WJ}-\mathrm{b}_{2^{\prime}-\mathrm{F}}+3 \mathrm{WJ}-\mathrm{c}_{\mathrm{LNA}}$; black: homogeneous $3 \mathrm{WJ}_{2^{\prime}-\mathrm{F}}, 3 \mathrm{WJ}-\mathrm{a}_{2^{\prime}-\mathrm{F}}+3 \mathrm{WJ}-\mathrm{b}_{2^{\prime}-\mathrm{F}}+3 \mathrm{WJ}-\mathrm{c}_{2^{\prime}-\mathrm{F}}$ ). 
TABLE 2. Summary of LNA/2'-F 3WJs

\begin{tabular}{|c|c|c|c|c|}
\hline 3WJs (16 nM) & Ratio of LNA & $T_{\mathrm{m}}\left({ }^{\circ} \mathrm{C}\right)$ & $K_{\mathrm{d}}(\mathrm{nM})$ & Half-life $(h)^{a}$ \\
\hline $3 \mathrm{WJ}-\mathrm{a}_{2^{\prime}-\mathrm{F}}+3 \mathrm{WJ}-\mathrm{b}_{2^{\prime}-\mathrm{F}}+3 \mathrm{WJ}-\mathrm{c}_{2^{\prime}-\mathrm{F}}$ & $0 / 3$ & 57 & $1.7 \pm 0.2$ & 7.7 \\
\hline $3 \mathrm{WJ}-\mathrm{a}_{2^{\prime}-\mathrm{F}}+3 \mathrm{WJ}-\mathrm{b}_{2^{\prime}-\mathrm{F}}+3 \mathrm{WJ}-\mathrm{c}_{\mathrm{LNA}}$ & $1 / 3$ & 74 & $3.1 \pm 0.3$ & 16.6 \\
\hline $3 W J-a_{2^{\prime}-F}+3 W J-b_{L N A}+3 W J-c_{L N A}$ & $2 / 3$ & $<95$ & $6.5 \pm 0.4$ & $>48$ \\
\hline $3 W J-a_{L N A}+3 W J-b_{L N A}+3 W J-c_{L N A}$ & $3 / 3$ & $>95$ & $1.5 \pm 0.3$ & $>48$ \\
\hline
\end{tabular}

circulation or within the urine excretion, it can be concluded that a high percentage of the LNA modified 3WJ samples were able to remain stable throughout the entirety of the in vivo studies. Thus, it is very exciting to find out that $3 \mathrm{WJ} \mathrm{LNA}_{\mathrm{LA}}$ is significantly more resistant to in vivo degradation and it can potentially improve drug delivery efficiency as it survives longer in vivo and may have a larger chance to deliver intact nanoparticles to the targets.

\section{Conclusion}

Studies on strand displacement, heat dissociation, chemical denaturation, serum assay, in vivo trial, as well as melting of homogeneous and hybrid complex lead to the conclusion that the order of the stabilizing effect of five different chemically modified oligonucleotides for phi29 pRNA 3WJ is PSDNA $<$ DNA $<$ RNA $<2$-F RNA $<$ LNA. The thermal stability of phi2 29 pRNA $3 \mathrm{WJ}$ can be easily tuned by incorporating varying oligonucleotides, resulting in a wide range of $T_{\mathrm{m}} \mathrm{s}$ from $21.2^{\circ} \mathrm{C}$ to over $95^{\circ} \mathrm{C}$. Incorporation of LNA into $3 \mathrm{WJ}$ would greatly protect it from rapid in vivo degradation, solving the instability problem of RNA nanoparticles. The exceptional stabilizing effect of LNA to phi29 pRNA 3WJ may be helpful to overcome pharmaceutical formulation difficulty, increase drug delivery efficacy, and render RNA nanotechnology clinically practical.

\section{MATERIALS AND METHODS}

DNA oligonucleotides and phosphorothioate-DNA strands were purchased from Integrated DNA Technologies. RNA strands, 2'-F U/C-substituted RNA strands (2'-F), and LNA-U/C-substituted RNA strands (LNA) were synthesized on AZCO DNA synthesizer using standard phosphoramidite chemistry with doubled coupling and oxidation time for LNA phosphoroamidites. RNA and 2'-F phosphoroamidites were purchased from Bioautomation, and LNA phosphoroamidites were purchased from Exiqon. Other chemicals for oligonucleotide synthesis were obtained from Novabiochem and used without further purification. All gels were scanned on Typhoon FLA 7000 (GE). The temperature-gradient gel electrophoresis (TGGE) system was from Biometra. Oligonucleotide concentration was calculated from the absorbance at $260 \mathrm{~nm}$ on Nanodrop 2000 (Fisher Scientific) and its extinction coefficient at $260 \mathrm{~nm}$. Fetal bovine serum was obtained from Sigma-Aldrich. $\left[\gamma^{-32} \mathrm{P}\right]$ ATP was obtained from PerkinElmer. Mice were ordered from Taconic Farms, Inc. All other chemicals were from Fisher Scientific.

\section{Assembly of $3 \mathrm{WJs}$}

Assembly of $3 \mathrm{WJ}$ s was performed by mixing equimolar molarity of corresponding strands in TMS buffer (50 mM TRIS pH $=8.0,100$ $\mathrm{mM} \mathrm{NaCl}, 10 \mathrm{mM} \mathrm{MgCl}_{2}$ unless otherwise specified) and annealed at $85^{\circ} \mathrm{C}$ for $5 \mathrm{~min}$ followed by slow cooling to $4^{\circ} \mathrm{C}$ over $\sim 40 \mathrm{~min}$. The $3 \mathrm{WJ}$ formations were confirmed on a $15 \%$ native PAGE in TBM running buffer $(89 \mathrm{mM}$ Tris, $200 \mathrm{mM}$ boric acid, and $5 \mathrm{mM}$ $\mathrm{MgCl}_{2}$ ) run at $120 \mathrm{~V}$ at $4^{\circ} \mathrm{C}$ for $90 \mathrm{~min}$. Gels were stained with ethidium bromide (EtBr).

\section{Temperature-gradient gel electrophoresis (TGGE)}

All assembled 3WJ samples were run on 12\% native PAGE in TMS buffer for $1 \mathrm{~h}$ at $100 \mathrm{~V}$. The $3 \mathrm{WJ}-\mathrm{c}$ was $5^{\prime}$ end radiolabeled using

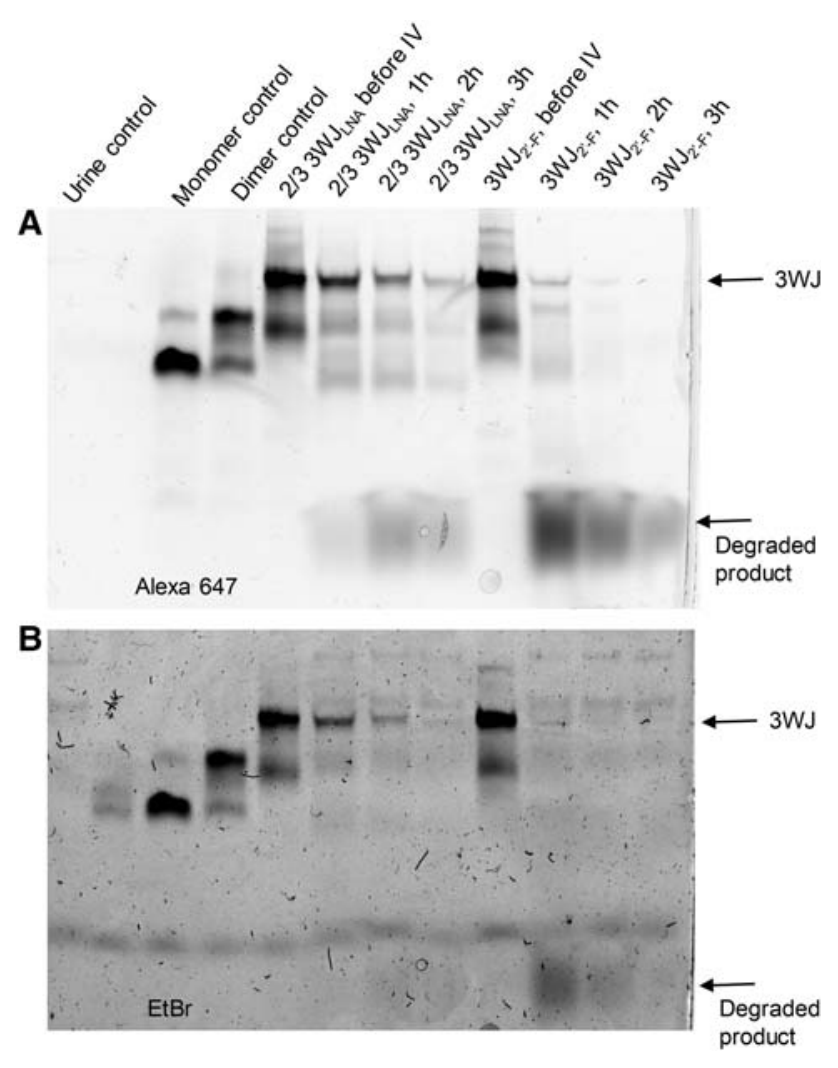

FIGURE 6. In vivo stability of hybrid $2 / 33 \mathrm{WJ}_{\mathrm{LNA}}$ and homogeneous $3 \mathrm{WJ}_{2^{\prime}-\mathrm{F} .}(A)$ Gel image under Alexa 647 channel. (B) Gel image under $\mathrm{EtBr}$ channel. Each lane is loaded with the same volume $(1 \mu \mathrm{L})$ of samples to give a comparison of the fluorescence intensity of each sample. 
$\left[\gamma^{-}{ }^{32} \mathrm{P}\right]$ ATP (PerkinElmer) in the hybrid $3 \mathrm{WJ}$ s. To compare the dissociation of $3 \mathrm{WJ}, 3 \mathrm{WJ}-\mathrm{c}$ (monomer) and $3 \mathrm{WJ}-\mathrm{a}+3 \mathrm{WJ}-\mathrm{c}$ (dimer) were used as control samples. The concentration of each sample was $10 \mu \mathrm{M}$ in the experiments. Gels were stained with $\mathrm{EtBr}$ and scanned prior to being dried and imaged by phosphorimaging. The concentration of each sample was $16 \mathrm{nM}$ in the characterization of LNA $/ 2$ '-F hybrid $3 \mathrm{WJ}$ s and gels were only imaged by phosphorimaging. All gel images were analyzed by ImageJ. All samples were repeated at least three times.

\section{Strand displacement}

Preassembled homogeneous 3WJs of different oligonucleotides were mixed with ${ }^{32} \mathrm{P}$-labeled $3 \mathrm{WJ}-\mathrm{c}_{\mathrm{LNA}}, 3 \mathrm{WJ}-\mathrm{c}_{2^{\prime}-\mathrm{F}}, 3 \mathrm{WJ}-\mathrm{c}_{\mathrm{RNA}}$, and $3 \mathrm{WJ}-\mathrm{c}_{\mathrm{DNA}}$, respectively. The final concentration of $3 \mathrm{WJ}$ and ${ }^{32} \mathrm{P}-$ labeled $3 \mathrm{WJ}$-c were $3 \mu \mathrm{M}$ in $9 \mu \mathrm{L}$. All samples were incubated at $37^{\circ} \mathrm{C}$ for $3 \mathrm{~h}$ followed by $12 \%$ Native PAGE separation at $110 \mathrm{~V}$ for $100 \mathrm{~min}$ at $4^{\circ} \mathrm{C}$. The gels were stained by EtBr and visualized on a Typhoon scanner prior to being dried and imaged by phosphorimaging.

\section{$K_{\mathrm{d}}$ measurement}

The apparent equilibrium dissociation constant $\left(K_{\mathrm{d}}\right)$ for assembled $3 \mathrm{WJ}$ s was measured by titrating $3 \mathrm{WJ}-\mathrm{a}+3 \mathrm{WJ}-\mathrm{b}$ into ${ }^{32} \mathrm{P}$-labeled $3 \mathrm{WJ}-\mathrm{c}$. The concentrations of $3 \mathrm{WJ}-\mathrm{a}$ and $3 \mathrm{WJ}-\mathrm{b}$ were identical, ranging from 0 to $256 \mathrm{nM}$, and the $3 \mathrm{WJ}$-c had a constant concentration of $1 \mathrm{nM}$. Each sample was heated at $95^{\circ} \mathrm{C}$ for $5 \mathrm{~min}$ and cooled to $4^{\circ} \mathrm{C}$ slowly over $50 \mathrm{~min}$ in TMS buffer. The formed $3 \mathrm{WJs}$ were resolved on $12 \%$ native PAGE at $4^{\circ} \mathrm{C}$ under the voltage of $110 \mathrm{~V}$ for $90 \mathrm{~min}$. Fractions of monomer, dimer, and $3 \mathrm{WJ}$ on each lane were quantified using ImageJ and fitted into a Hill1 equation in Origin 8 following our previous publications (Binzel et al. 2014). All samples were repeated at least three times.

\section{Resistance to heat denaturation}

LNA/2'-F hybrid 3WJs were assembled in TMS buffer and the concentration of $3 \mathrm{WJ}$ is $16 \mathrm{nM}$. The $3 \mathrm{WJ}-\mathrm{c}_{\mathrm{LNA}}$ was $5^{\prime}$ end labeled using $\left[\gamma^{-}{ }^{32} \mathrm{P}\right] \mathrm{ATP}$ in the formed 3WJ. LNA 3WJ was mixed with nonradiolabeled $3 \mathrm{WJ}-\mathrm{C}_{\mathrm{LNA}}$ over a range of concentrations from 0 to 800 $\mathrm{nM}\left(0-50\right.$ equivalents). The mixed samples were heated at $95^{\circ} \mathrm{C}$ for $5 \mathrm{~min}$ and cooled to $4^{\circ} \mathrm{C}$ quickly followed by resolving on $12 \%$ native PAGE in TBM buffer. Control samples were $3 \mathrm{WJ}$ $\mathrm{c}_{\mathrm{LNA}}$ (monomer), $3 \mathrm{WJ}-\mathrm{c}_{\mathrm{LNA}}+3 \mathrm{WJ}-\mathrm{a}_{\mathrm{LNA}}$ (dimer), and $3 \mathrm{WJ}-\mathrm{c}_{\mathrm{LNA}}$ $+3 \mathrm{WJ}-\mathrm{a}_{\mathrm{LNA}}+3 \mathrm{WJ}-\mathrm{b}_{\mathrm{LNA}}$ (trimer, $\left.3 \mathrm{WJ}\right)$ without heat denaturation. The $3 \mathrm{WJ}-\mathrm{c}_{\mathrm{LNA}}$ was radiolabeled in the control samples. Gels were exposed to phosphorimaging screen overnight and visualized on a Typhoon scanner. All samples were repeated at least three times.

\section{Resistance to $8 \mathrm{M}$ urea denaturation}

LNA $/ 2$ '-F hybrid $3 \mathrm{WJ}$ s were assembled in TMS buffer and the $3 \mathrm{WJ}-$ $c_{\text {LNA }}$ was $5^{\prime}$ end labeled using $\left[\gamma^{-}{ }^{32} \mathrm{P}\right]$ ATP in the formed $3 \mathrm{WJ}$. The $3 \mathrm{WJ}$ samples were mixed with nonradiolabeled $3 \mathrm{WJ}-\mathrm{c}_{\mathrm{LNA}}$ over a range of concentrations from 0 to $1600 \mathrm{nM}$ ( 0 to 100 equivalents). All 3WJ samples were mixed with $12 \mathrm{M}$ urea to give a final concentration of $16 \mathrm{nM}$ and the urea concentration was $8 \mathrm{M}$. The mixed samples were incubated at $37^{\circ} \mathrm{C}$ for $30 \mathrm{~min}$ prior to $8 \mathrm{M}$ urea denaturing gel analysis. Gels were exposed to phosphorimaging screen overnight and visualized on a Typhoon scanner. All samples were repeated at least three times.

\section{Stability against $\mathbf{5 0} \%$ serum}

LNA $/ 2$ '-F hybrid $3 \mathrm{WJs}$ were assembled in TMS buffer and mixed with FBS. The final concentrations of $3 \mathrm{WJ}$ samples were $1 \mu \mathrm{M}$ and FBS were $50 \%$. Samples were incubated at $37^{\circ} \mathrm{C}$ for a maximum of $48 \mathrm{~h}$. Samples were taken out of a thermocycler and stored at $-80^{\circ} \mathrm{C}$ until analysis on $15 \%$ native PAGE. Gels were run at $4^{\circ} \mathrm{C}$ under the voltage of $110 \mathrm{~V}$ for $90 \mathrm{~min}$ and stained with $\mathrm{EtBr}$.

\section{In vivo stability}

$3 \mathrm{WJ}$ were assembled in PBS buffer and the $3 \mathrm{WJ}-\mathrm{C}_{2^{\prime}-\mathrm{F}}$ was labeled with Alexa647. One hundred microliters of $20 \mu \mathrm{M}$ assembled $3 \mathrm{WJs}$ were injected into $\mathrm{BALB} / \mathrm{c}$ mice and the urine was completely collected. The urine samples were resolved on $15 \%$ native PAGE. Gels were run at $100 \mathrm{~V}$ for $100 \mathrm{~min}$ at $4^{\circ} \mathrm{C}$. The gels were stained by $\mathrm{EtBr}$ and scanned under both the Alexa647 channel and $\mathrm{EtBr}$ channel.

\section{SUPPLEMENTAL MATERIAL}

Supplemental material is available for this article.

\section{ACKNOWLEDGMENTS}

The research in P.G.'s laboratory was supported by National Institutes of Health grants R01EB019036, U01CA207946, and UH3TR000875. We thank Hongran Yin, Zhefeng Li, Mario Vieweger, and Congcong $\mathrm{Xu}$ for their helpful discussion and assistance in experiments. P.G.'s Sylvan G. Frank Endowed Chair position in Pharmaceutics and Drug Delivery is funded by the CM Chen Foundation. P.G. is the consultant of Oxford Nanopore Technologies and Nanobio Delivery Pharmaceutical Co. Ltd., as well as the cofounder of Shenzhen P\&Z Bio-medical Co. Ltd. and its subsidiary US P\&Z Biological Technology LLC.

Received July 17, 2017; accepted October 3, 2017.

\section{REFERENCES}

Afonin KA, Cieply DJ, Leontis NB. 2008. Specific RNA self-assembly with minimal paranemic motifs. J Am Chem Soc 130: 93-102.

Afonin KA, Bindewald E, Yaghoubian AJ, Voss N, Jacovetty E, Shapiro BA, Jaeger L. 2010. In vitro assembly of cubic RNA-based scaffolds designed in silico. Nat Nanotechnol 5: 676-682.

Afonin KA, Viard M, Koyfman AY, Martins AN, Kasprzak WK, Panigaj M, Desai R, Santhanam A, Grabow WW, Jaeger L, et al. 2014. Multifunctional RNA nanoparticles. Nano Lett 14: 5662-5671.

Agrawal S, Zhang X, Lu Z, Zhao H, Tamburin JM, Yan J, Cai H, Diasio RB, Habus I, Jiang Z, et al. 1995. Absorption, tissue distribution and in vivo stability in rats of a hybrid antisense oligonucleotide following oral administration. Biochem Pharmacol 50: 571-576.

Allerson CR, Sioufi N, Jarres R, Prakash TP, Naik N, Berdeja A, Wanders L, Griffey RH, Swayze EE, Bhat B. 2005. Fully 2'-modified oligonucleotide duplexes with improved in vitro potency and 
stability compared to unmodified small interfering RNA. $J$ Med Chem 48: 901-904.

Betts L, Josey JA, Veal JM, Jordan SR. 1995. A nucleic acid triple helix formed by a peptide nucleic acid-DNA complex. Science 270: $1838-1841$.

Binzel DW, Khisamutdinov EF, Guo P. 2014. Entropy-driven one-step formation of Phi29 pRNA 3WJ from three RNA fragments. Biochemistry 53: 2221-2231.

Binzel DW, Khisamutdinov E, Vieweger M, Ortega J, Li J, Guo P. 2016 a. Mechanism of three-component collision to produce ultrastable pRNA three-way junction of Phi29 DNA-packaging motor by kinetic assessment. RNA 22: 1710-1718.

Binzel D, Shu Y, Li H, Sun M, Zhang Q, Shu D, Guo B, Guo P. 2016 b. Specific delivery of miRNA for high efficient inhibition of prostate cancer by RNA nanotechnology. Mol Ther 24: 1267-1277.

Burnett JC, Rossi JJ. 2012. RNA-based therapeutics: current progress and future prospects. Chem Biol 19: 60-71.

Calin GA, Croce CM. 2006. MicroRNA signatures in human cancers. Nat Rev Cancer 6: 857-866.

Chworos A, Severcan I, Koyfman AY, Weinkam P, Oroudjev E, Hansma HG, Jaeger L. 2004. Building programmable jigsaw puzzles with RNA. Science 306: 2068-2072.

Crick FH. 1958. On protein synthesis. Symp Soc Exp Biol 12: 138-163.

Cui D, Zhang C, Liu B, Shu Y, Du T, Shu D, Wang K, Dai F, Liu Y, Li C, et al. 2015. Regression of gastric cancer by systemic injection of RNA nanoparticles carrying both ligand and siRNA. Sci Rep 5: 10726.

de la Peña M, Dufour D, Gallego J. 2009. Three-way RNA junctions with remote tertiary contacts: a recurrent and highly versatile fold. RNA 15: 1949-1964.

De Mesmaeker A, Altmann KH, Waldner A, Wendeborn S. 1995. Backbone modifications in oligonucleotides and peptide nucleic acid systems. Curr Opin Struct Biol 5: 343-355.

Diamond JM, Turner DH, Mathews DH. 2001. Thermodynamics of three-way multibranch loops in RNA. Biochemistry 40: 6971-6981.

Dibrov SM, McLean J, Parsons J, Hermann T. 2011. Self-assembling RNA square. Proc Natl Acad Sci 108: 6405-6408.

Duckett DR, Murchie AI, Lilley DM. 1995. The global folding of fourway helical junctions in RNA, including that in U1 snRNA. Cell 83: 1027-1036.

Elmen J, Thonberg H, Ljungberg K, Frieden M, Westergaard M, Xu Y, Wahren B, Liang Z, Orum H, Koch T, et al. 2005. Locked nucleic acid (LNA) mediated improvements in siRNA stability and functionality. Nucleic Acids Res 33: 439-447.

Felden B, Florentz C, Giegé R, Westhof E. 1996. A central pseudoknotted three-way junction imposes tRNA-like mimicry and the orientation of three $5^{\prime}$ upstream pseudoknots in the $3^{\prime}$ terminus of tobacco mosaic virus RNA. RNA 2: 201-212.

Gai D, Zhao R, Li D, Finkielstein CV, Chen XS. 2004. Mechanisms of conformational change for a replicative hexameric helicase of SV40 large tumor antigen. Cell 119: 47-60.

Geary C, Rothemund PW, Andersen ES. 2014. A single-stranded architecture for cotranscriptional folding of RNA nanostructures. Science 345: 799-804.

Ghildiyal M, Zamore PD. 2009. Small silencing RNAs: an expanding universe. Nat Rev Genet 10: 94-108.

Grabow WW, Jaeger L. 2014. RNA self-assembly and RNA nanotechnology. Acc Chem Res 47: 1871-1880.

Grabow WW, Zakrevsky P, Afonin KA, Chworos A, Shapiro BA, Jaeger L. 2011. Self-assembling RNA nanorings based on RNAI/II inverse kissing complexes. Nano Lett 11: 878-887.

Guo P. 2010. The emerging field of RNA nanotechnology. Nat Nanotechnol 5: 833-842.

Guo P, Haque F. 2013. RNA nanotechnology and therapeutics. CRC Press, Boca Raton, FL.

Guo P, Zhang C, Chen C, Trottier M, Garver K. 1998. Inter-RNA interaction of phage phi29 pRNA to form a hexameric complex for viral DNA transportation. Mol Cell 2: 149-155.

Gyi JI, Conn GL, Lane AN, Brown T. 1996. Comparison of the thermodynamic stabilities and solution conformations of DNA $\cdot$ RNA hy- brids containing purine-rich and pyrimidine-rich strands with DNA and RNA duplexes. Biochemistry 35: 12538-12548.

Hansen ME, Bentin T, Nielsen PE. 2009. High-affinity triplex targeting of double stranded DNA using chemically modified peptide nucleic acid oligomers. Nucleic Acids Res 37: 4498-4507.

Heidenreich O, Benseler F, Fahrenholz A, Eckstein F. 1994. High activity and stability of hammerhead ribozymes containing $2^{\prime}$-modified pyrimidine nucleosides and phosphorothioates. J Biol Chem 269: 2131-2138.

Hohng S, Wilson TJ, Tan E, Clegg RM, Lilley DM, Ha T. 2004. Conformational flexibility of four-way junctions in RNA. $J \mathrm{Mol}$ Biol 336: 69-79.

Jaeger L, Leontis NB. 2000. Tecto-RNA: one-dimensional self-assembly through tertiary interactions. Angew Chem Int Ed Engl 39: 2521-2524.

Jaeger L, Westhof E, Leontis NB. 2001. TectoRNA: modular assembly units for the construction of RNA nano-objects. Nucleic Acids Res 29: 455-463.

Jasinski D, Haque F, Binzel DW, Guo P. 2017. Advancement of the emerging field of RNA nanotechnology. ACS Nano 11: 11421164.

Karkare S, Bhatnagar D. 2006. Promising nucleic acid analogs and mimics: characteristic features and applications of PNA, LNA, and morpholino. Appl Microbiol Biotechnol 71: 575-586.

Kaur H, Arora A, Wengel J, Maiti S. 2006. Thermodynamic, counterion, and hydration effects for the incorporation of locked nucleic acid nucleotides into DNA duplexes. Biochemistry 45: 7347-7355.

Kawasaki AM, Casper MD, Freier SM, Lesnik EA, Zounes MC Cummins LL, Gonzalez C, Cook PD. 1993. Uniformly modified $2^{\prime}$-deoxy-2'-fluoro phosphorothioate oligonucleotides as nucleaseresistant antisense compounds with high affinity and specificity for RNA targets. J Med Chem 36: 831-841.

Khisamutdinov EF, Jasinski DL, Guo P. 2014. RNA as a boiling-resistant anionic polymer material to build robust structures with defined shape and stoichiometry. ACS Nano 8: 4771-4781.

Khisamutdinov EF, Jasinski DL, Li H, Zhang K, Chiu W, Guo P. 2016. Fabrication of RNA 3D nanoprism for loading and protection of small RNAs and model drugs. Adv Mater 28: 100079-100087.

Khvorova A, Watts JK. 2017. The chemical evolution of oligonucleotide therapies of clinical utility. Nat Biotechnol 35: 238-248.

Layzer JM, McCaffrey AP, Tanner AK, Huang Z, Kay MA, Sullenger BA. 2004. In vivo activity of nuclease-resistant siRNAs. RNA 10: $766-771$.

Leontis NB, Lescoute A, Westhof E. 2006. The building blocks and motifs of RNA architecture. Curr Opin Struct Biol 16: 279-287.

Lescoute A, Westhof E. 2006. Topology of three-way junctions in folded RNAs. RNA 12: 83-93.

Li H, Lee T, Dziubla T, Pi F, Guo S, Xu J, Li C, Haque F, Liang X, Guo P. 2015. RNA as a stable polymer to build controllable and defined nanostructures for material and biomedical applications. Nano Today 10: 631-655.

Li H, Zhang K, Pi F, Guo S, Shlyakhtenko L, Chiu W, Shu D, Guo P. 2016. Controllable self-assembly of RNA tetrahedrons with precise shape and size for cancer targeting. Adv Mater 28: 7501-7507.

Liu Q, Paroo Z. 2010. Biochemical principles of small RNA pathways. Annu Rev Biochem 79: 295-319.

Lundbaek JA, Andersen OS. 1994. Lysophospholipids modulate channel function by altering the mechanical properties of lipid bilayers. J Gen Physiol 104: 645-673.

Lundin KE, Gissberg O, Smith CI. 2015. Oligonucleotide therapies: the past and the present. Hum Gene Ther 26: 475-485.

Mercer TR, Dinger ME, Mattick JS. 2009. Long non-coding RNAs: insights into functions. Nat Rev Genet 10: 155-159.

Morlando M, Ballarino M, Fatica A, Bozzoni I. 2014. The role of long noncoding RNAs in the epigenetic control of gene expression. ChemMedChem 9: 505-510.

Moss EG. 2001. RNA interference: it's a small RNA world. Curr Biol 11: R772-R775. 
Ouellet J, Melcher S, Iqbal A, Ding Y, Lilley DM. 2010. Structure of the three-way helical junction of the hepatitis $\mathrm{C}$ virus IRES element. RNA 16: 1597-1609.

Piao X, Xia X, Bong D. 2013. Bifacial peptide nucleic acid directs cooperative folding and assembly of binary, ternary, and quaternary DNA complexes. Biochemistry 52: 6313-6323.

Rauzan B, McMichael E, Cave R, Sevcik LR, Ostrosky K, Whitman E, Stegemann R, Sinclair AL, Serra MJ, Deckert AA. 2013. Kinetics and thermodynamics of DNA, RNA and hybrid duplex formation. Biochemistry 52: 765-772.

Rettberg CC, Prere MF, Gesteland RF, Atkins JF, Fayet O. 1999. A threeway junction and constituent stem-loops as the stimulator for programmed -1 frameshifting in bacterial insertion sequence IS911. J Mol Biol 286: 1365-1378.

Severcan I, Geary C, Chworos A, Voss N, Jacovetty E, Jaeger L. 2010. A polyhedron made of tRNAs. Nat Chem 2: 772-779.

Sharma A, Haque F, Pi F, Shlyakhtenko L, Evers BM, Guo P. 2015. Controllable self-assembly of RNA dendrimers. Nanomedicine 12: 835-844.

Shaw JP, Kent K, Bird J, Fishback J, Froehler B. 1991. Modified deoxyoligonucleotides stable to exonuclease degradation in serum. Nucleic Acids Res 19: 747-750.

Shu D, Moll WD, Deng Z, Mao C, Guo P. 2004. Bottom-up assembly of RNA arrays and superstructures as potential parts in nanotechnology. Nano Lett 4: 1717-1723.

Shu D, Shu Y, Haque F, Abdelmawla S, Guo P. 2011. Thermodynamically stable RNA three-way junctions for constructing multifuntional nanoparticles for delivery of therapeutics. Nat Nanotechnol 6: 658-667.

Shu Y, Pi F, Sharma A, Rajabi M, Haque F, Shu D, Leggas M, Evers BM, Guo P. 2014. Stable RNA nanoparticles as potential new generation drugs for cancer therapy. Adv Drug Deliv Rev 66: 74-89.

Shu D, Li H, Shu Y, Xiong G, Carson WE, Haque F, Xu R, Guo P. 2015. Systemic delivery of anti-miRNA for suppression of triple negative breast cancer utilizing RNA nanotechnology. ACS Nano 9: 9731-9740.

Stein CA, Castanotto D. 2017. FDA-approved oligonucleotide therapies in 2017. Mol Ther 25: 1069-1075.

Tiemann K, Rossi JJ. 2009. RNAi-based therapeutics-current status, challenges and prospects. EMBO Mol Med 1: 142-151.

Vester B, Wengel J. 2004. LNA (Locked Nucleic Acid): high-affinity targeting of complementary RNA and DNA. Biochemistry 43: 13233-13241.

Westhof E, Masquida B, Jaeger L. 1996. RNA tectonics: towards RNA design. Fold Des 1: R78-R88.

Wiedenheft B, Sternberg SH, Doudna JA. 2012. RNA-guided genetic silencing systems in bacteria and archaea. Nature 482: 331-338.

Xu Z, Sun Y, Weber JK, Cao Y, Wang W, Jasinski D, Guo P, Zhou R, Li J. 2017. Directional mechanical stability of Bacteriophage phi29 motor's 3WJ-pRNA: extraordinary robustness along portal axis. Sci $A d v$ 3: e1601684.

Yingling YG, Shapiro BA. 2007. Computational design of an RNA hexagonal nanoring and an RNA nanotube. Nano Lett 7: 2328-2334.

Zhang C. 2009. Novel functions for small RNA molecules. Curr Opin Mol Ther 11: 641-651.

Zhang R, Lu Z, Zhao H, Zhang X, Diasio RB, Habus I, Jiang Z, Iyer RP, Yu D, Agrawal S. 1995. In vivo stability, disposition and metabolism of a "hybrid" oligonucleotide phosphorothioate in rats. Biochem Pharmacol 50: 545-556.

Zhang H, Endrizzi JA, Shu Y, Haque F, Sauter C, Shlyakhtenko LS, Lyubchenko Y, Guo P, Chi YY. 2013. Crystal structure of 3WJ core revealing divalent ion-promoted thermostability and assembly of the Phi29 hexameric motor pRNA. RNA 19: 1226-1237.

Zhang Y, Leonard M, Shu Y, Yang Y, Shu D, Guo P, Zhang X. 2017. Overcoming tamoxifen resistance of human breast cancer by targeted gene silencing using multifunctional pRNA nanoparticles. ACS Nano 11: 335-346. 

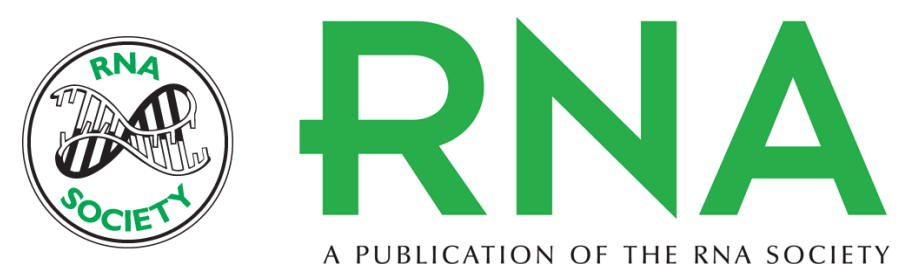

A PUBLICATION OF THE RNA SOCIETY

\section{Assessment and comparison of thermal stability of phosphorothioate-DNA, DNA, RNA, 2 '-F RNA, and LNA in the context of Phi29 pRNA 3WJ}

Xijun Piao, Hongzhi Wang, Daniel W. Binzel, et al.

RNA 2018 24: 67-76 originally published online October 19, 2017

Access the most recent version at doi:10.1261/rna.063057.117

Supplemental Material

References

Creative Commons License

Email Alerting Service
http://rnajournal.cshlp.org/content/suppl/2017/10/19/rna.063057.117.DC1

This article cites 74 articles, 15 of which can be accessed free at: http://rnajournal.cshlp.org/content/24/1/67.full.html\#ref-list-1

This article is distributed exclusively by the RNA Society for the first 12 months after the full-issue publication date (see http://rnajournal.cshlp.org/site/misc/terms.xhtml). After 12 months, it is available under a Creative Commons License (Attribution-NonCommercial 4.0 International), as described at http://creativecommons.org/licenses/by-nc/4.0/.

Receive free email alerts when new articles cite this article - sign up in the box at the top right corner of the article or click here.

To subscribe to $R N A$ go to:

http://rnajournal.cshlp.org/subscriptions 